\title{
equity activity
}

\section{Marlène Benquet}

Paris Dauphine University, France

\begin{abstract}
How do private equity firms decide on a fair price for a business? Drawing on 76 semistructured interviews, this article contributes to the sociology of finance and valuation studies by showing that pricing companies is not just a valuation operation but also a capitalrepartition issue. In so doing, it shows how concrete, local pricing methods contribute to the financialisation of the economy through the creation of a new capital accumulation centre. The article's ethno-accounting approach describes three pricing steps: first, the capital access rules applicable to the private equity firm members (the price rationale); second, the expectations about the capital that can be transferred from the business to the private equity firm (the theoretical price level); and third, the transaction participant coordination mechanisms (culminating in the actual price). This description of the practices and concepts inherent in business valuation sidesteps the traditional divide between price formation in constructivist concepts of value as well as price discovery in substantivist concepts of value. Instead, value is defined as the expectation of a transfer of capital from the productive sphere to the private equity firm.
\end{abstract}

\section{Keywords}

Private equity, ethno-accounting, accumulation centre, pricing companies, financial evaluation

\section{Introduction}

How do private equity firms decide on a fair price for a business? Answering this question is one of the central tasks undertaken by the investors in these firms, who are key actors in the second phase of the economy's financialisation. ${ }^{1}$ The 280 French private equity firms, which were non-existent in the late 1980s, are now ranked third on the world private equity market in 
terms of sums invested since 2006, behind only New York and London, and second worldwide for the number of business acquisitions. Private equity firms are also significant analytically, because they operate at the point where the financial sphere meets the productive sphere. They buy majority shareholdings in businesses, which they restructure for resale, over an average five-year period, in order to generate a financial return for their institutional investors (banks, insurance firms, foreign pension funds and family estates). Private equity firms make their financial gain not from the profits of the businesses acquired, but by appropriating part of the capital gains made on their price speculation. Private equity firms are thereby instrumental in the reconfiguration of the productive sphere (Auvray et al., 2016), in promoting management mechanisms (Foureault, 2014; Benquet, 2013), and in maximising 'shareholder value' (Fligstein and Feeland, 1995; Lordon, 2000).

The capital gains made by this new form of capital circulation and accumulation depend directly on the targeted businesses' acquisition and sale prices. This makes pricing a particularly crucial moment in the distribution of money among sectors and individuals. The purpose of this article is to show how concrete, local pricing methods contribute to creating such a massive capital accumulation centre. This analysis of pricing methods sits at the intersection of social studies of finance and the sociology of prices. It builds on ten years of research on business valuation, which defines value institutionally as a product of the instruments, perceptions and beliefs of the transaction participants (e.g. Beckert, 2011; see also Boussard, 2013). Expanding on the project of denaturalising so-called economic 'facts' (Steiner and Vatin, 2009), these studies approach financial evaluation by analysing the networks of actors involved in the transactions (White, 1981; Godechot, 2009), their governance by formal and informal rules (Uzzi and Lancaster, 2004), and the appraisers' working conditions and terms of employment (Cochoy and Dubuisson, 2000; Boussard and Dujarier, 2014). These studies investigate meso-level social mechanisms and show how socialisation and career management processes combine to produce prices.

More specifically, the literature on valuation studies, right up to the launch of a dedicated journal of that name in 2013, shows how sociotechnical mechanisms contribute to price formation (MacKenzie and Millo, 2003; Beunza and Stark, 2003; Callon and Muniesa, 2003; Muniesa and Teil, 2006; Doganova, 2014). For example, the book Capitalization, written by an authorial collective at the French Centre for the Sociology of Innovation (CSI) (Muniesa et al., 2017), deals with a particular valuation process known as 'capitalisation'. This is defined as a set of mechanisms that transform objects into 'assets', which are defined in terms of their future value (Muniesa et al, 2017: 129). This approach points to the pervasiveness of the investors' focus on and methods of valuing objects in the world. Yet in order to bring the issue of valuation back into the field of social sciences, this approach has more or less left the question of capital and its accumulation by the wayside. The beliefs, rules and tools that frame the pricing context are considered in isolation from the analysis of the money they circulate. Centred on the cultural and technical aspects of the valuation process, these approaches sometimes forget that they are embedded in broader social relations and simply focus on the interactions between investors, entrepreneurs and market actors. They cannot see the full picture in which valuation processes are also accumulation mechanisms that produce hierarchies and rankings between individuals and social groups. In other words, these approaches tend to consider value independently from profit, and capitalisation separately from capitalism.

By contrast, the purpose here is to describe valuation and pricing operations as they are embedded in the enrichment devices that give them meaning. The study's focus is not on the spread of one device in the social world - one mathematical formula (Doganova, 2014), one 
accounting standard (Chiapello, 2005), or one career management method (Boussard, 2013) - but on capital itself as it runs through a multitude of mathematical, legal, professional and economic devices. That is not to say that capital can be grasped outside of these mechanisms, but to stress that the particularity of the network is the thing it circulates (Latour, 2012: 48). This topographical approach to capital supports an ethnographic methodological position. The price formation steps are constituted at the micro-sociological level, hence they can be observed and analysed by an empirically grounded analysis (Cottereau, 1998: 4). The point of shifting the focus from the tool to the use, or from a sociology of accounting to ethnoaccounting (Baciocchi and David, 2006; Cottereau, 2007), is to explain individuals' valuation references, i.e. the pricing norms, in terms of both economic efficiency and social justice, based on which they decide on 'fair' prices. This article describes individuals' accounts of their practices in order to present three sources of prices: first, the capital access rules applicable to the private equity firm members (the price rationale); second, the expectations about the capital that is transferable from the business to the private equity firms (the theoretical price level); and third, the transaction participant coordination mechanisms (culminating in the actual price). This description of the practices and concepts inherent in business valuation sidesteps the traditional divide between 'price formation' in constructivist accounts of value and 'price discovery' in substantivist accounts by redefining value as the expectation of a transfer of capital from the productive sphere to the private equity firm.

The analysis that follows concerns the French private equity market. This market first emerged in the 1980s, ten years after the American private equity market from which it has imported some of its financial practices, legal standards and valuation methods. Nevertheless, unlike the American situation (Fligstein, 1990, 2001), the French private equity market rallied government, industry shareholders and traditional financiers to its cause right from its early days in the 1980s (Benquet and Bourgeron, 2019). However, despite the development of the French financial system, the investment banks have remained much less powerful in France than in the United States (US) and pension funds are extremely marginal (O'Sullivan, 2007). Judging from the existing literature on valuation methods in the US (Ortiz, 2014; Ho, 2009), these differences between France and the US do not appear to have had any major effect on private equity investors' accounting and valuation methods. A collective study, which compares private equity investors' valuation methods in five different countries, argues: "The American and French valuation approaches are more similar to each other, while these countries differ widely in terms of industry maturity or governance system" (Manigart et al., 2000: 396). On the question of the beneficiaries of this capital accumulation method, this French case study confirms the findings of Erturk et al. (2007) on the growing role of financial intermediaries in the ownership of part of the value created by businesses. The position these "business high earners" occupy in these financial transactions "creates opportunities for value skimming" (Erturk et al., 2007: 53). In the specific case of French private equity, it is also the case that, "while private equity publicly claims to represent ownership with control ... the undisclosed generic business model is the control of ownership through constructing a hierarchy of ownership claims for debt and equity suppliers in the capital market" (Erturk et al., 2010: 543).

Yet the relative importance of the different intermediaries and debt suppliers in these 'value capture' processes takes a particular form in France. Formerly state-owned banking establishments continue to play a key role in value capture. Although the influence of the American merchant banks can be felt in France, they remain less powerful on the whole than in the US. Among the institutional investors, it is the insurance companies that play the role of American pension funds. These companies have a highly marginal level of market penetration 
in France. Lastly, since 2008, the real heavyweight in the private equity sector in France has been the Fonds Stratégique d'Investissement, which became BPI France in 2012.

This study of French private equity valuation practices is based on qualitative data drawn from interviews and observations conducted between 2011 and 2016. A total of 76 semistructured interviews were conducted with the different professionals involved in business transactions (merchant bankers, lending bankers, business lawyers, auditors, investors and financial directors), including 16 with private equity firm members. The observations were made in different professional financial situations and on leveraged buyout (LBO) training courses run by the French Association of Financial Directors and Management Controllers (DFCG). The recorded interviews - lasting from one-and-a-half to three hours - were always conducted in the respondents' respective offices. The sample was built by 'snowballing' from three initial contacts made with a private equity firm member and two merchant bankers, with each interviewee agreeing at the end of the interview to put me in contact with two or three other colleagues. The interviews met with a positive reception in this professional environment, where I was careful to respect business confidentiality. Building the sample through successive recommendations raised the financiers' interest in cultivating and maintaining cooperative relationships with each other. Although they work in a highly competitive sphere, as much in terms of the businesses to be acquired as the jobs to be secured and the remuneration to be negotiated, their professional success depends on the intensity of the give-and-take relationships they nurture amongst themselves. These relationships make for exchanges of crucial information and favours with respect to the financial transactions themselves (sectors in which to invest, bank interest rates granted, state of businesses in the process of acquisition, etc.), but also with respect to each actor's career development and professional opportunities. One of their professional socialisation imperatives is to nurture contacts with an extended network of colleagues and fellow alumni whose knowledge could be decisive in the job market. These professionals therefore need to find opportunities to see each other. Being recommended and making a recommendation in turn helped in maintaining these long-distance peer relationships.

\section{Situated accounting and price rationale}

The first step toward understanding the way the financiers calculate is to set out in search of documents that show their specific accounting methods. The valuation model they use is actually an Excel document containing approximately twenty columns and a thousand-odd lines. Seen as the embodiment of the private equity firm's investment strategies and a cornerstone of its financial performance, this model is treated by its users as a trade secret wherein disclosure would threaten a decisive competitive advantage. Yet these models are virtually identical from one firm to the next, save for the different corporate colours and typefaces. The hypothesis put forward here is that this homogeneity of accounting methods is based neither on technical uniformity, due to the use of the same computing tool, nor on a shared neoclassical conception of the value of the companies. It is based on a community situated in capital circulation channels, i.e. on shared methods of financial gain.

\section{Owning the capital by exercising the right to double-skimming}

The form this document takes, i.e. its layout and the indicators and formulas it contains, is the same across all the firms studied and financing packages considered (see Table 1). However, 
its content, i.e. the figures in the different cells, is changed incessantly, right up to the day when the transaction finally takes place or is abandoned. This formal infrastructure is common to the multitude of prices formed and shapes their rationale, as opposed to their level, i.e. their specific and particular amount. ${ }^{2}$

Table 1. Formal valuation model used by the private equity firms. Source: Author's own.

\begin{tabular}{|c|c|}
\hline \multicolumn{2}{|c|}{ Date of acquisition (-4 years) / -3 to -1 years / Year of acquisition / +1 to 6 years / Year of resale } \\
\hline 1. Target business & $\begin{array}{l}\text { Target business' income statement, balance sheet and } \\
\text { cash flow statements }\end{array}$ \\
\hline 2. Transaction structure & $\begin{array}{l}\text { Sources and application of funds, details of transaction } \\
\text { costs and debt servicing }\end{array}$ \\
\hline 3. Holding company's business & $\begin{array}{l}\text { Holding company's income statement, balance sheet and } \\
\text { cash flow statements }\end{array}$ \\
\hline 4. Consolidated accounts & $\begin{array}{l}\text { Target business and holding company's income } \\
\text { statement, balance sheet and cash flow statements }\end{array}$ \\
\hline 5. Exit hypothesis & Value of the business, value of the shares \\
\hline 6. Transaction summary & $\begin{array}{l}\text { Target business' income statement, consolidated } \\
\text { accounts' cash flow statements, regulated financial ratios }\end{array}$ \\
\hline
\end{tabular}

This valuation model is not an accounting representation of the 'target' business, but of the entire acquisition transaction. It is divided into six parts. The first part sums up 'the target's business' and consists of a summary of the business' income statement, balance sheet and cash flow statements. The second, 'the transaction structure', details the sources and application of the funds used to finance the acquisition. The third, 'the holding company's business', sums up the financial statements of the holding company set up as a tax optimisation instrument to centralise the capital used to acquire the business. The fourth part presents the consolidated accounts, i.e. the aggregated statements of accounts for the holding company and the business. The fifth catalogues the possible resale scenarios for the business. The sixth and last section sums up the entire transaction, including the target's income statement, the consolidated accounts' cash flow statements and, last but not least, the expected return on investment.

The structure of this model is the result of the private equity firms' position in the capital circulation network and the resulting enrichment methods (see Figure 1 on next page). 


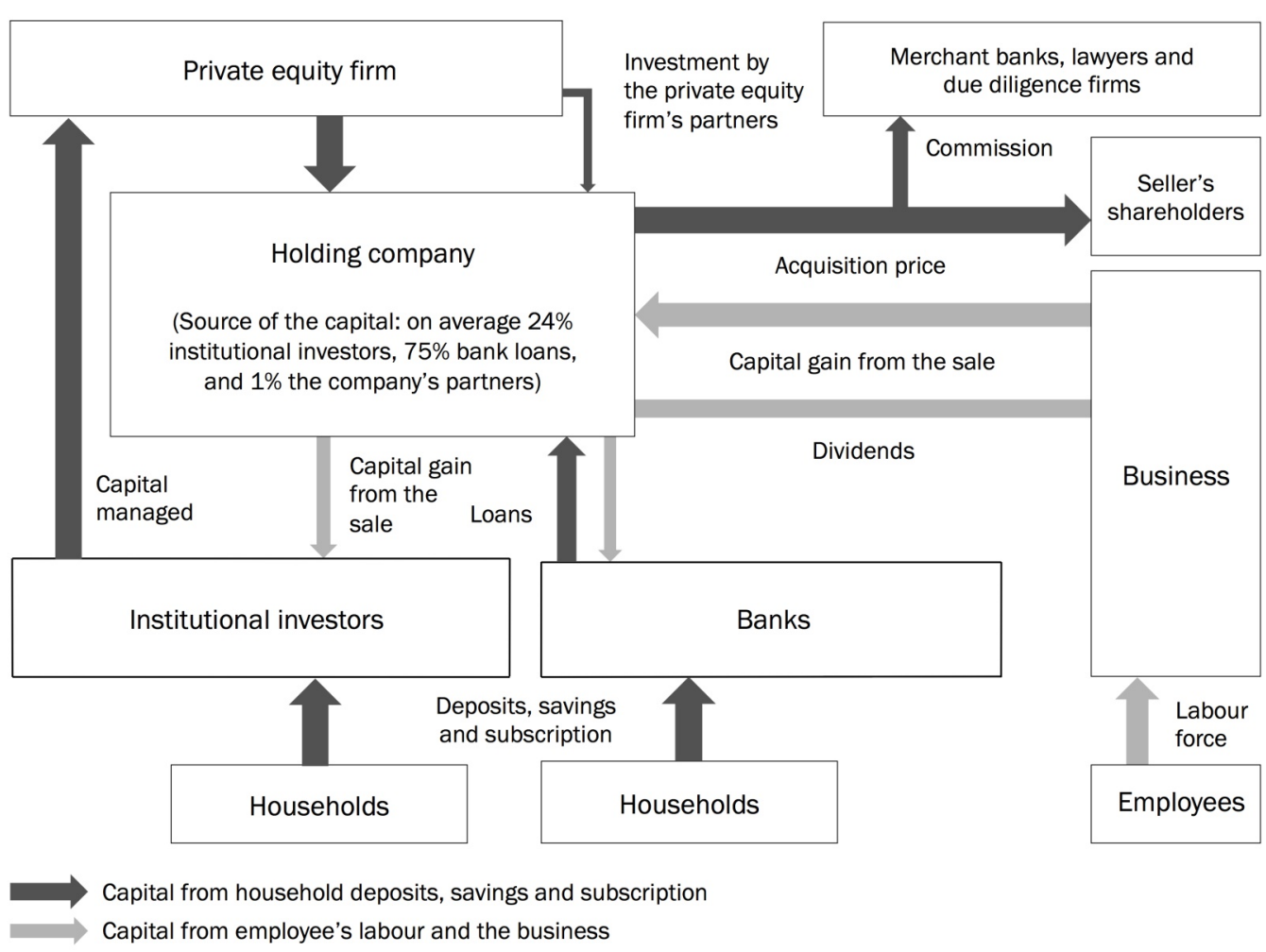

Figure 1. Circulation of capital in business acquisition transactions conducted by private equity firms. Source: Author's own.

Two main channels feed their profits. The source of the first is in the acquired business itself. The management companies are remunerated by their ownership of $20 \%$ of any capital gain made on the resale of the business (carried interest), once it exceeds the $8 \%$ reserved for the institutional investors. The size of this capital gain depends on both the difference between acquisition price and sale price, and on the change in the ratio of debt-to-equity in the capital invested to acquire the business. The private equity firms operate on the basis of leveraged buyouts (LBOs), which consist of the use of massive bank debt financing schemes to fund the purchase of a business' shares. This bank debt financing is reimbursed by the business' dividends, which transit through a holding company. At constant acquisition and resale prices, the potential capital gain therefore increases pro rata to the repayment of the acquisition debt. This is what the valuation model's 'transaction structure' section measures.

The second channel forms a link between the management companies and the public treasury. It does not appear in the capital circulation figure, because it is not a capital flow, but rather an absence of flow due to the tax breaks associated with these operations. It is described in the fourth section of the valuation model on the consolidation of the business and holding company's accounts. Consolidation entitles the firms to what Article $223 \mathrm{~A}$ of the French General Tax Code defines as tax consolidation. This consists of combining the taxable profits and losses of the different companies in a group such that the taxable profits of one company are offset by the losses of another. This measure was facilitated by the 2004 Budget Act, whereby a buyer acquiring over 95\% of a company's shares is entitled to merge the acquired business and the acquiring holding company into one taxable firm. The acquired business' profits are then reduced by the indebted holding company's deficit and the tax base reduced to the point where it often disappears. ${ }^{4}$ As a managing partner told me: 
The operating company [the business] is supposed to pay tax. It works it into the holding company and, that way, it's never be paid. Because your holding company benefits from tax consolidation. Tax consolidation means that firms can be made non-taxable. (Interview, 22 April 2012)

At this point in the capital circulation network, the firm's investment of 1-2\% of the funds invested - the rest being made up of equity provided by institutional investors and debt - is transformed into a 20\% capital gain. This system, known as '2-20' (Appelbaum and Batt, 2014), works like a siphon. Once the business is placed in the new system, the capital flows are automatically diverted to the transaction's participants. A managing partner of a private equity firm put it like this:

I take over a company, it's worth so much. I finance the buyout: 70 debt and 30 capital. And I pray every day that the company will continue to tick over nicely. And bingo, I milk the cow. Automatically, without doing a thing, I double my money. (Interview, 10 July 2012)

This method of accumulation is based on a legal infrastructure established in the $1980 \mathrm{~s}$ when the government switched to defending the public interest by serving the interests of private finance (Lemoine, 2016). In 1984, at odds with the French Commercial Code, which stipulates that, "A company shall not advance funds, grant loans or grant sureties to enable a third party to subscribe or purchase its own shares" (Article L. 225-216, author's translation), the Management Buyout (MBO) legalised the establishment of a holding company for the purpose of repaying a company's acquisition debt using its dividends. The creation and extension of this special status effectively turned this misappropriation of corporate funds into an arrangement guaranteed by law. Moreover, in the 1990s and 2000s, tax on these transactions was steadily reduced by a combination of effective lobbying by the French Private Equity Association (AFIC) ${ }^{5}$ and the French government's deregulatory shift. The 2004 Budget Act established the tax consolidation scheme enabling actors to "build a little tax haven on their own doorstep" (Cozian and Deboissy, 2014: 789), and capital gains on sales were gradually exempted from tax. The government hence created a capital accumulation method, hitherto non-existent in the 1980s, based on double-skimming of the businesses' dividends and the Public Treasury.

\section{Placing the business in a new capital circulation network}

The indicators used in the model's five parts reveal the business characteristics on which investors focus their attention. Their aim is to extract 'cash-basis' accounts from the accrual accounting in the business' financial statements by translating the different elements of the business' balance sheet and income statement into expenses and income actually disbursed and received. These indicators are entered for the three or four years prior to the supposed acquisition date and the five or six years after it. The data on the future years are obviously projections that do not correspond to actual accounting values. However, the data on the past years are also the product of a reprocessing process, which makes them empirically unverifiable.

This alternative, counterfactual accounting is not designed to analyse the actual situation, but to analyse a possibility. It is essentially a thought process that consists of imagining what might or might have been the business' incomings and outgoings if it were placed in the centre of the capital circuits defining the private equity firm's situation. The model is built to evaluate the effect of the different input variables (level of debt, envisaged 
investments, variation in turnover, etc.) on an output variable: the rate of profit measured by the ROI (rate of return on investment). This is defined by the equation:

$R O I=(\text { Net end value/equity })^{\wedge}(1 / n)-1$

where ' $n$ ' represents the investment period. The net end value depends directly on the level of debt reduction achieved over the holding period, i.e. the total volume of capital transferred from the business to the holding company and then to the banks that funded the transaction. A director of equity interests for a private equity firm said:

The LBO models are not very complicated. Depending on the business' cash generation, we try to see what amount of debt and what debt structure it can bear. The idea is to put a minimum of equity to work and secure a maximum of debt, because that's what will give you a great ROI. (Interview, 19 September 2016)

The model hence applies 'other-things-being-equal' reasoning across the board by calculating the effects of the different modes of financing and management decisions on the transaction's overall ROI. The model thereby makes the price the consequence of an expected rate of profit. What comes first, both chronologically and analytically, is the ROI below which the private equity firm prefers not to invest. Contrary to step-based approaches to transactions in which the price pre-exists the financing - "They give a price and then structure the deal" (Foureault, 2014: 211, emphasis added) - the price appears as the product of the combination of a financing method and a remuneration requirement. It does not precede the financing package designed to pay it. It is the result of it. Price formation here originates in a teleological rationale where the targeted rate of profit plays the role of the end cause that determines the level of all the other variables.

\section{Building and using a valuation reference}

Given that the reference rate of profit is not generated by the model, but assumed by it, we need to step outside of the frame and the company valuation process to find how it is developed. The reference ROI for firm members is the valuation reference they take to estimate the advisability of the transaction. This concept effectively replaces the price/thing couplet with the actual price-things-valuation reference triad (Cottereau, 2014: 2). This triad is not developed on the basis of an abstract profit aspiration, but real possibilities for financial gain present in the appraiser's particular context. It can be equated here with the notion of opportunity cost, which states: "The capital must be remunerated at a level commensurate with what it could find elsewhere" (Lordon, 2000: 122, author's translation).

The sector's associations and trade press often place this reference profit rate at $20 \%$. In the interviews, however, fund members spoke about its variability depending on the valuation's macro-social context (represented mainly by the key lending rate), sector context and local context. At the management company level, the reference profit rate decreases the further away it is from the date of raising the capital since, in addition to a percentage on the capital gains on sales, fund members earn a $2 \%$ management commission on the managed capital if they succeed in investing it in a company. A lending banker and structured finance director at the $\mathrm{CIC}$ explained:

The target ROI [reference profit rate] depends mainly on the competitive environment and the context. Funds have a lot of money to place right now, so they have to invest. If they don't invest, they're dead. 
Literally. So they're prepared to invest at any price. Even if they pay too much. Prices at the moment depend on the personal career problems of a hundred guys working in private equity firms. (Interview, 12 September 2016)

The reference ROI also depends on the actual performance of the operations in progress in the firm. Good performances balance out poor performances when presenting earnings figures to investors. Last but not least, it depends on the competitor firms' reference ROls and actual ROls, which the institutional investors compare with each new raising of capital. The valuation model's architecture thus reveals the price rationale, which is the outcome of the incorporation into the price of the position occupied by those in charge of setting it. This notion shows the inextricable link between the valuation instruments and their users. As the expression of a situated remuneration method, the tool used here supports the financial gain of those who occupy a prior position in the capital circulation network. It moreover contradicts a definition of prices as a reflection of the intrinsic value of the businesses. This considerable presumption, common to classical and neoclassical economics, where it is modelled mainly by the Discounted Cash-Flow method (Orléan, 2011), makes business valuation the examination of a decontextualized value expressed in a price independent of the appraisers' remuneration method and transaction funding arrangements.

The homogeneity of the valuation model used by the private equity firms is therefore based on their situated, communal valuations. Yet if this model's structure stamps a common rationale on all the prices it generates, how does it produce different price levels?

\section{Evaluating the realisable skim}

The figures entered in the valuation model's different cells are the outcome of a set of devices and beliefs used to determine the price level. This is the maximum theoretical price above which the return on the acquisition would be below the participants' reference profit rate. It is the outcome of work to govern the future by maximising the transfer of capital from the business to the private equity firms.

\section{Investigating the business activity behind the accounts}

The first steps in this task consist of an investigation into the business itself. The purpose of this investigation is to estimate the business' real activity, behind its accounting formalisation, and determine what it could become based on its current situation. The goal of the firm members is to develop a strategic line capable of maximising the business' profitability and measuring the effect of this management method on their potential profits. This inquiry transforms an indeterminate situation (the state of the business) into "one that is determinate in its constituent distinctions and relations" (Dewey, 1991: 108), and which facilitates action (buy or don't buy). Its purpose is prescriptive. It is not conducted to say what the business is worth, but whether it is worth buying.

The private equity firm members justify the investigation by their distrust, as a matter of principle, of official and especially accounts-based representations of the business. In keeping with the findings of the sociology of quantification, the accounts department is perceived not as a recording chamber for economic transactions, but as an optimised representation of the business (Chiapello, 2008).

Investors' distrust in this way drives the creation of a professional sphere dedicated to examining accounts. An investment director told me: 
When you discover a possibility for a transaction, regardless of how the proposal came your way, the principle is to doubt everything. Because the figures can always be fiddled and presented to you in a certain light. (Interview, 4 March 2012)

Their suspicions are raised first of all by what is seen as inadequate regulation of the financial statements. Private equity firm members and financial directors hence deplore the extent of alterations permitted by the General Chart of Accounts. Former Vivarte financial director (an organisation which trains financial directors) said:

Indicators like EBITDA are good news, because they are not very regulated. What do you do to avoid affecting your EBITDA ${ }^{6}$ You charge off operating expenses as extraordinary events. You could even say that a hugely expensive advertising campaign that brings your EBITDA crashing down is an extraordinary event. (Interview, 4 October 2014)

Some financial indicators key to the appraisal of the company, such as the debt-to-EBITDA ratio, can also be altered, in particular by the equity cure procedure, which consists of reducing the debt ratio by incorporating retrospectively injected capital into its calculation. The Director continued: "Now, that's some magic trick. It means you can add capital not to your debt, but to your EBITDA so that, abracadabra, now you respect your ratio" (Interview, 5 October 2014).

In addition, they feel that the auditing procedures are hindered by the professional standards of the groups in charge of conducting the audits. An investment director told me:

Accounts certification certifies absolutely nothing. The auditor is paid by the business and has known the financial director and the team for ten years. In any case, he can't do an awful lot. For example, let's say the business makes a huge provision for litigation. The auditor says to himself, 'That's really too much'. He calls the firm's lawyer. And what does the lawyer say? That his bar association prohibits him from assessing litigation. In other words, he is not at liberty to answer the question. (Interview, 13 September 2016)

Their distrust is exacerbated by uncertainty as to how much cooperation they are getting from the business' management. As they have no alternative access to the business, they depend on its management to measure any deviations between its real activity and its accounting formalisation. An investment director for BPI France said:

Management have a key role as they are the ones who provide the information. You're dependent on them to know what's really going on in the business. If they don't want to work with you, things are going to be very hard. (Interview, 22 May 2012)

Seen as the sole guardians of what the private equity firm wants to obtain, i.e. an empirically-grounded knowledge of the business' profitability, the managers are suspected of manipulating decisive information to defend their professional interests to the detriment of the interests of new shareholders.

In order to overcome this problem, and the associated risk of 'ignorance costs', the private equity firms began promoting assets and liabilities guarantee agreements in the early 1990s. These agreements were supposed to protect buyers from discoveries made after the acquisition. Ultimately, however, they were deemed too unreliable. They were dropped in the late 1990s and replaced across the board by due diligence, i.e. standardised assessments of the business' situation. The perimeter of transaction participants hence expanded and the division of acquisition labour became more sophisticated (Larminat, 2012: 78) around the private equity firms, which remained sole custodians of the decisions to invest. 


\section{Commissioning professionals capable of returning standardised conclusions}

The firms in charge of performing the different due diligence assessments - strategic, financial, legal and tax-based - form a professional sphere (Boussard and Dujarier, 2014) dominated by a few companies. ${ }^{7}$ They are structured in a way that has standardised the scheduling of the different sequences in the acquisition process. Take the following exchange that I (MB) had with a private equity firm partner (PE):

PE: On the whole, we all work the same way. There is a timeframe of approximately ten months from the moment a business is presented to us to buy to the moment we sign.

MB: And what happens over the year?

PE: We first check in-house that we are interested in the business, at least as it is presented to us by its management. Then we choose the consultants who will launch the due diligence and we start work with a firm on the strategic plan and the financing. Three to four months later, we approve a business plan and organise a meeting with the management to get to know them, ask our questions and so on ... Next we open a data room ${ }^{8}$ where we check all the information. Then, two to three months later, the due diligence reports come back. A massive all-in check and then decision time.

This due diligence reduces the investors' uncertainty as to the profitability of the business, but it does not dispel it entirely. The accuracy of due diligence is dependent on the accuracy of the information on which it is based. Yet the quantity and quality of the documents made available by the managers to the buyers in the data room are the result of a trade-off between two conflicting constraints. The first is to protect the confidentiality of the data on the business, to prevent potentially damaging leaks escaping from the web of interpersonal links in the Parisian mergers and acquisitions sector. ${ }^{9} \mathrm{~A}$ merchant banker told me:

There's a pub not far from here where all of Paris gathers after work ... That's part of my job ... That's where we discuss things. We test the water. We check out the others' states of mind. We listen to rumours about this or that company. We do each other favours. (Interview, 23 April 2015)

The second constraint is to earn the trust of the potential buyers by giving them access to a sufficient amount of quality information. In response to these two constraints, the business' management prioritises the buyers it considers to be the best defenders of its own business interests. It therefore proceeds not to alter the composition of the data room, which would constitute a breach of the compulsory equality of treatment between potential purchasers, but to inform potential buyers of the documents about where to place their attention. The former Vivarte Financial Director revealed that:

A good way to hide an important piece of information on the company is simply to leave it in the middle of poorly classed archives. It's hardly likely that the buyers will chance across it in three days and you can say that the document was definitely there. (Interview, 5 October 2014)

Lastly, investors' distrust is fuelled by the way in which the consulting firms are paid, in the form of a commission charged on the transaction amount (of around $2 \%$ if the transaction goes through, and from $0.1 \%$ to $0.5 \%$ if it is abandoned) and not on any profitability. An investment director in a private equity firm said: 
Consulting bankers make you do stupid things. That's the commission effect. If it's a rotten deal, they make you jump in. They run a dirty race. It's a bit of a vicious world. We need LBO team leaders who know how to say, 'No'. (Interview, 19 September 2016)

Contrary to the idea of informational efficiency, which assumes that "prices fully reflect all available information" (Fama, 1970: 383) and that holding this information procures neither profit nor advantage (Jensen, 1978), the investigation conducted here is motivated by a dual belief, justifying the remuneration paid the consulting firms, that the information is both unevenly distributed and decisive for financial performance.

The second part of the investigation conducted by the investors consists of developing a future management strategy for the business that will maximise their potential profits. The challenge is to manage to tie in the findings of the investigation on the business with the investors' beliefs as to its future growth in order to produce a credible financial gain scenario for the different participants in the transaction.

\section{Building a collective belief about the business's future growth}

The business growth scenario presented in the strategic due diligence reports needs to both maximise the profit for the different transaction actors and meet with their approval in terms of its price. Consensus is sought by collectively developing a plausible scenario. The proposed management strategy, or business plan for the company, is based on the findings of the financial, social and legal due diligence reports on the business and on comparative data drawn from the trade press and public and private economic analysis bodies concerning other companies presenting similar characteristics. A director in a mergers and acquisition firm said:

For the business plan, we already have the findings of the other due diligence reports, so we know what state the business is in. Then we look for more information. It's a job in which you spend a lot of time reading the press and perusing reports on this or that sector. I regularly see a couple of guys who I know have a good analysis of the economic situation. (Interview, 1 July 2012)

The investigator's work consists of subsuming the particular case of the business studied under appropriate categories (companies of equivalent size, in the same sector, the same region, etc.), for which all or part of the French financial centre shares valuation conventions, i.e. reference frameworks that serve as a compass for the particular valuations (Cottereau, 2014: 11). These conventions are the result of trends and mimetic rationales. Here, the analysis of a business consists of comparing it with other firms about which a consensus already exists. This approach is based on a shared belief in the partial reproducibility of business performance. The scenario produced is not considered to be true or probable - it is not based on the idea of future predictability - but it is plausible in that it could form the subject of a reasonable forecast in view of the dominant ideas of its time (Genette, 1969: 73). This is the first method used to produce a consensual scenario.

\section{Disseminating a consensual valuation}

The second method is not associated with the scenario's content, but the way in which it is disseminated. This forward-looking investigation is developed in liaison with the other potential transaction participants, essentially the members of the merchant bank approached to provide consulting services on the transaction, lead lending bank representatives and its 
consultants, and the sellers. Its results are not publicly released, since this would weaken the private equity firm's position vis-à-vis its competitors for the purchase. Instead, the results are circulated among the potential participants for reciprocal adjustments and gradual permeation to produce a dominant opinion on price among the actors. The investigators' skill here is not so much technical as relational. Their central position in the private equity sector conditions their role as aggregator of all the actors' valuations and their capacity to convince the different transaction participants of their own convictions. An Investment Director for a private equity firm said:

The bankers' [consultants] who work on a deal have often already been to see all the participants ... So with everyone talking to each other to some extent, we end up agreeing. There are always leaks. So we always know more or less where the others are at. And ultimately, everyone ends up in the same ballpark. (Interview, 19 September 2016)

At the end of the day, via the production of a plausible co-developed hypothesis, the investigation culminates in a price level being set above which the amount of appropriable capital would be less than the private equity firm's reference profit rate.

Turning now from practices to the way people talk about them, the question is to look into how these actors perceive the business valuation hypothesis in order to describe how they understand the status of prices.

\section{Believing in the price set by a business valuation}

The private equity firm members describe the valuation of the business' dynamics using the lexical fields of belief and fiction. Their local conception of the future contradicts both its probabilistic and its performative definition. A managing partner at a private equity firm said:

The analyst's job is simple. It is to take all the hypotheses underlying the business plan and say to you, 'Do I believe it or not?' So at some point, it's a question of belief. (Interview, 6 June 2012)

Capital accumulation is supported here by the collective development of plausible fictional expectations about the future (Beckert, 2016). The business' growth hypothesis is not based on what can be proved, but on what needs to be believed. The probabilistic concept of time used by neoclassical approaches, based on the idea that the future can be reduced to a list of probabilisable events, implies making possible world states correspond to a return and a risk coefficient (Morgenstern, Von Neumann 1944; Savage, 1954). In the private equity firm valuation model, however, risk is grasped in the form of a sensitivity table. The influence of each explanatory variable (net income, debt amount, labour costs, etc.) on the explained variable (rate of return on investment) is measured 'other things being equal', without ever asking after the probability that the considered hypothesis will actually come true.

These actors ultimately share a definition of the future as irreducibly uncertain (Orléan, 2011: 284) and an understanding of risk as unmeasurable (Lordon, 2008: 22). These representations of the future are built into the prices actually paid. The actors hence govern the future by aiming to reduce the range of possibilities; they aim to bring about a version of the future conducive to their financial gain by aggregating the devices that manage the business, its debt and its taxation. Nor is the future seen as the outcome of a performative definition of the actions and beliefs of these financiers. The way in which they govern the future does not work on the model of a self-fulfilling prophecy, but through a constant effort to reconfigure businesses through material devices (Callon and Muniesa, 2003), such as the 
modes of governance imposed in LBO transactions. The way in which these investors incorporate the question of time into their pricing method is based on a rationality that could be called consequentialist: it aims to estimate the consequences of different possible actions in a concrete situation. The price here is the uncertain expectation of the effects of their actions on potential profits.

Yet the price level arrived at by the investigation is a theoretical price, because it is individual. It encompasses solely the expectations of the private equity firm members. What are the processes by which it is converted into an actual collective price enabling the transaction to take place?

\section{Actual price: From theoretical price to transaction price}

A leveraged buyout (LBO) is a collective transaction that obviously involves the private equity firm, but also the lending banks, the transaction consultants (merchant banks and lawyers), the selling shareholder, and the business' management. For the maximum theoretical price set by the private equity firm to become an actual price, it has to secure for each of the participants, in view of its particular capital access rules, a higher capital gain than their reference profit rate. To build this collective interest into the transaction, the participants factor in the other participants' profit aspirations alongside their own reference profit rates throughout the valuation process.

\section{Factoring in other participants' valuation references}

The first step towards developing an actual price is to designate the beneficiaries of the potential capital gain. The choice of the beneficiaries of the potential gains is made at the company level and from among the individuals within the companies selected. Within the management company, only the partners have an interest in the capital gain by means of the carried interest. A private equity firm partner said:

It's a star system, because there's a huge amount of money involved. If a two-billion-euro fund makes twice the stake and $20 \%$ is distributed to the firm's partners ... plus the $2 \%$ management fee ... Then incredible amounts have changed hands. (Interview, 26 June 2012)

Within the evaluated business, certain management team members, whose loyalty the future shareholders want to secure, share in any future profits by means of a contract called a management package. This highly lucrative contract for the lucky few lays down the terms and sum of the remuneration received depending on the capital gain made when the business is resold. The former Vivarte Financial director told me that:

It's easy. All you have to do is wait for the CEO to call you to tell you you're in. Often, he gives you the document and says, 'Sign it there in front of me'. He doesn't even let you take it home to show your wife or have it looked over by a lawyer. (Interview, 4 October 2014)

The lending banks can earn their share of the transaction in a number of ways. They can 'obtain the loan mandate' and thereby become the 'lead bank' for the transaction (origination). They can 'take a ticket', i.e. a portion of the loan placed under the control of the lead bank (syndication). Lastly, they can purchase claims on the loan on the secondary market (securitisation). ${ }^{10}$ These three ways of taking a share correspond to three means of 
remuneration: from the interest on the capital provided, from the commission paid by the banks to the lead bank to obtain the right to issue these instruments, and from the capital gain that can be made when speculating on the claims turned into securities. A lending banker described the process:

\footnotetext{
Origination is finding investment opportunities and trying to land the mandate. And when you land the mandate, you execute it sometimes alone and sometimes with others ... The basic principle of all these operations is that the higher up the pyramid you are and the further upstream you get involved, the more money you make and the better you know the project. (Interview, 7 April 2015)
}

The consulting banks earn their share when the transaction is concluded, with a commission of approximately $2 \%$ of the transaction total. The commission is not paid out of the business' profits or any capital gain made on resale, but out of the capital placed under management in the private equity firm by the institutional investors. A consulting banker told me: "The consulting bank is a cost centre. [We can make a living] because we sell products such as credit, even when it's not well done" (Interview, 4 February 2014). The different beneficiaries of the potential profits evaluate the maximum business purchase price that will satisfy their profit aspirations, knowing that this price will only become an actual price if it accommodates everyone's enrichment aspirations. Competition between participants for capital ownership is therefore limited by their common interest in the transaction taking place. If nothing happens, the capital will not circulate and no one will make a financial gain. The situated accounting conducted by the private equity firm is therefore an attempt to reconstruct the other participants' situated accounting at the same time. The last section of the valuation model, the 'transaction summary', hence features estimates of the rates of return on investment (ROI) for the lending banks, the management, the consulting bank and the lawyers.

Coordination is therefore not obtained, on the model of The Fable of the Bees (Mandeville, 1714), by the simple uncoordinated juxtaposition of the individual interest calculations. Transactional interdependence leads each party's economic valuations to factor in the others' economic valuations at the different transaction stages.

\section{Securing the profits}

Collective interest is also built by setting up collective arrangements to secure the profits. These are designed mainly to externalise the financial risks of the transaction onto both the institutional investors (hence households) and the business (hence employees). The main risk is a discrepancy between expectations about business profitability and actual profitability. If the business' dividends are not sufficient to repay the debt taken out to purchase it, then the profit expectations are not borne out and the capital invested may itself be wiped out.

This risk is firstly externalised onto the institutional investors by the regulatory third-party asset management mechanism, which serves to help investors' benefit from the returns on capital without owning the capital. The private equity firms exercise management rights over capital that is twice delegated, from households to the institutional investors and then to the private equity firms. Unlike other types of shareholders, especially industrial and public shareholders, they invest in businesses' equity that they do not hold on their balance sheet assets. This new form of financial intermediation (Glachant et al., 2008) makes financial gain conditional on the power of federation rather than capital ownership. It is no longer the economic capital held before the fact, but the investors' capital base that gives them access to ownership of the profits. 
A director of a private equity firm said: "Financial services are basically occupations where what you sell ... is your address book. It's a people business" (Interview, 6 March 2012). If the capital is wiped out, the losses are not borne by the private equity firms, which are merely managers of the capital, but by the institutional investors. Moreover, part of their remuneration is guaranteed by the unconditional payment of management fees. A managing partner of a private equity firm explained:

There's ten of us and we manage 500 million euros. Let's say we earn a commission of $1.5 \%$ per year. Do the maths and we make 7.5 million euros a year, and there's ten of us in 400 square metres of offices. You take out the offices and the rest is for us! Paribas Affaires Industrielles Partners is one of the largest French private equity firms. There are thirty of them and they make 30 million euros a year [in management fees]. When you're earning that kind of a salary, you don't care if the money makes a profit [in the form of a capital gain]. (Interview, 26 June 2012)

The financial risks are also externalised onto the business itself (Chambost, 2016) via banking documentation, which has swollen in volume since the early 2000s. These contracts, signed by all the participants to the transaction, cover all the business' possible management and financing operations with clauses stipulating whether they are authorised. They also cover the different difficulties the business might face and the agreed arrangements to contain their financial impacts. The banking documentation thereby constitutionalises the private equity firm's control of the management of the business and minimises the risk of any fall in its profits affecting the profits of the acquisition participants.

These practices of risk externalisation to the institutional investors and the business itself thereby build a secure capital accumulation centre and a centre of financial irresponsibility for these beneficiaries (Larminat, 2016).

This form of collective financial gain based on skimming the capital produced by a business is sometimes criticised, in particular by members of the acquired businesses, including when they have benefited from the accumulation technique in the past. The former Vivarte financial director expressed these thoughts sharply: "Banks, consulting firms, private equity firms: they're thick as thieves! And here we are, the nice financial director who sets the business to work to pay all those people" (Interview, 5 October 2014). Or in the words of a former consulting banker, now financial director of a medium-sized enterprise:

It [the private equity firms and consulting bankers] remains fundamentally a profession of bloodsuckers. You don't create value. You're not the source of value. And that's one of the problems. And then I've always found the profit level disgraceful ... When I see now [that I am a financial director in a business] how hard it is to generate one euro of income, raking in 3, 4, 5 million euros is really quite shocking. (Interview, 23 February 2012)

This method of capital accumulation moreover contradicts the neoclassical rule, which holds that returns are a function of risk.

\section{Conclusion}

This ethno-accounting approach to understanding financial calculation reveals a three-step price conditioning process within private equity firms. Prices are situated. Their rationality is contextual. They are set within a particular institutional configuration. The notion of price rationale indicates that prices are inextricably linked with the position occupied by those who set them and are embedded in their capital accumulation methods. They then become 
hypothetical. The investors determine the theoretical price level by gauging the possible effects of their management of a business on its earnings. Their rationality here is consequentialist. It embraces a certain definition of the future as something that their actions can influence, although they are unable to either predict or model it. Lastly, prices are collective. Arriving at the actual price involves building a collective interest in the acquisition of the business by factoring in the enrichment aspirations of all the participants and employing collective devices to secure the profits. The notion of actual price points to how pricing is a valuation operation as much as it is a capital distribution operation.

This pragmatic approach to pricing therefore sidesteps the analytical divide between prices formed by the transaction mechanisms, where the reference to value serves simply as the justification, and prices discovered, where value is seen as their objective basis. It effectively rules out of the question a match between prices and value and redefines prices as the situated valuation of quantities of profits that can be appropriated by harnessing capital flows from household savings and the exploitation of workers. Lastly, it supports replacing the notion of 'value' with that of 'valuation':

The disadvantage with the word value is that it detaches this notion from the contexts in which it makes sense ... The notion of valuation, on the other hand, echoes the fact that these are transactions made up of at least three elements: where there is a notion of value $V$, the question is to analyse how agents $A$ put actions or a line of conduct $B$ into an valuation relation with a reference framework $C$. (Cottereau and Marzok, 2012: 16)

In so doing, the ethno-accounting lens resembles the common form of economic evaluation and other forms of evaluation - religious, moral and cultural - and makes a case for economic science to be brought back into the social sciences.

\section{Acknowledgments}

This article was originally published in Sociétés contemporaines as 'Fixer le prix des entreprises: Pour une ethnocomptabilité de l'activité des fonds d'investissement' (Benquet, 2018). It has been translated and reprinted with the permission of Presses de Sciences Po. Additional material was added to the translated version of the paper based on feedback from an anonymous reviewer and the editors of Finance and Society.

\section{Notes}

1. Financialisation is defined here as "a novel pattern of accumulation" (Krippner, 2005: 174) based not on a new mode of production but a new mode of distribution of capital gains. It has been at work in France since the 1990s to the benefit of non-banking institutions, which take majority shareholdings in businesses redefined as commodities available for trade.

2. It is preferable to talk here about price rationale rather than price form, in order to underline this formal infrastructure's key role in understanding prices, as well as to avoid any confusion with the price form concept used by Orléan (2011: 189), which for him designates the monetary dimension underpinning price objectivity.

3. The business' cash flow can be assessed at different moments in the business' activity. It is not an accounts item, but a financial item.

4. The possibility of one day seeing these transactions defined as misappropriation of corporate funds is a nagging concern for the sector's professionals and the tax consultants who advise them. 
The law considers that if there is evidence that a holding company has been set up for the sole purpose of tax optimisation and that it has no activity of its own, which is the case with holding companies set up for LBOs, then this could be defined as a breach of law. However, each time the relevant authorities have been consulted on this matter, they have ruled out the possibility (see Cozian, and Deboissy, 2014).

5. AFIC, the French Private Equity Association, which became the French Association of Investors for Growth in 2012, is one of the leading professional associations for private equity actors.

6. EBITDA stands for Earnings Before Interest, Taxes, Depreciation, and Amortization.

7. Among the most well-known due diligence firms are OC\&C Strategy Consultants and Roland Berger Strategy; among the financial due diligence firms, the 'big four' are Ernst \& Young, Deloitte, PwC, and Eight Advisory; the leading social and legal due diligence firms are Ernst, Gide and Lamy.

8. Data rooms are physical or virtual spaces in which managers place confidential information on the business. Access to these data rooms is limited in time to between one and five days, and is reserved for private equity firm representatives and the due diligence consultants.

9. Boussard's (2015) study of the careers of the actors involved in these transactions confirms the local nature of the interpersonal networks leveraged professionally and the relevance of the scale of the markets (Paris, Lyon, London, Luxembourg, etc.) to understanding the ways in which information and individuals circulate.

10. The secondary market trades financial assets already created on the primary market.

\section{References}

Appelbaum, E. and Batt, R. (2014) Private Equity at Work: When Wall Street Manages Main Street. New York: Russell Sage Foundation Publications.

Auvray, T., Dallery, T. and Rigot, S. (2016) L'entreprise liquidée: La finance contre l'investissement. Paris: Michalon.

Baciocchi, S. and David, J. (eds.) (2006) Frédéric Le Play: Eléments d'épistémologie et de science sociale. Les Études sociales, 142-143-144 (II-2005/2006): 5-223.

Beckert, J. (2011) Where do prices come from? Sociological approaches to price formation. SocioEconomic Review, 9(4): 757-86.

Beckert, J. (2016) Imagined Futures: Fictional Expectations and Capitalist Dynamics. Cambridge, MA: Harvard University Press.

Benquet, M. (2013) Encaisser: Enquête en immersion dans la grande distribution. Paris: La Découverte.

Benquet, M. (2018) Fixer le prix des entreprises: Pour une ethnocomptabilité de l'activité des fonds d'investissement. Sociétés contemporaines, 110(2): 89-117.

Benquet, M. and Bourgeron, T. (2019) Accumuler le capital: Sociohistoire du capital-investissement en France, 1982-2017. Actes de la recherche en sciences sociales, 229(4): 46-71.

Beunza, D. and Stark, D. (2003) Outils de marché: Sociotechnologie de l'arbitrage dans une salle de marché à Wall Street. Réseaux, 122(6): 63-108.

Boussard, V. (2013) Qui crée la création de valeur? La nouvelle revue du travail, 3/2013. Available at: <http://nrt.revues.org/1020>. Accessed 21 November 2019.

Boussard, V. (2015) De l'espace hybride au monde social: La coordination dans le marché en abyme des transactions d'entreprise. L'année sociologique, 65(2): 357-90.

Boussard, V. and Dujarier, M.-A. (2014) Les représentations professionnelles en question: Le cas des intermédiaires dans les fusions-acquisitions. Sociologie du Travail, 56(2): 182-203.

Callon, M. and Muniesa, F. (2003) Les marchés économiques comme dispositifs collectifs de calcul. Réseaux, 122(6): 189-232. 
Chambost, I. (2016) Les ressorts de la domination financière: Le cas des LBO. In: Chambost, I., Lenglet, M. and Tadjeddine, Y. (eds.) La fabrique de la finance: Pour une approche interdisciplinaire. Villeneuve d'Ascq: Presses universitaires du Septentrion, 171-82.

Chiapello, E. (2005) Les normes comptables comme institution du capitalisme: Une analyse du passage aux normes IFRS en Europe à partir de 2005. Sociologie du travail, 47(3): 362-82.

Chiapello, E. (2008) La construction comptable de l'économie. Idées économiques et sociales, 152(2) : 26-34.

Cochoy, F. and Dubuisson-Quellier, S. (2000) Les professionnels du marché: Vers une sociologie du travail marchand. Sociologie du travail, 42(3): 359-68.

Cottereau, A. (1998) Sens de l'injustice, réalisme économique et espace public: Approches sociologique et historique. Programme de recherche et d'enseignement. Paris.

Cottereau, A. (2007) Le Play économiste. In: Frédéric Le Play: Eléments d'épistémologie et de science sociale. Les Étude sociales, 142-143-144 (II-2005/2006): 119-92.

Cottereau, A. (2014) La notion de prix de référence. Séminaire Pratique d'enquête et sens de la réalité sociale. EHESS Paris, 7 Janvier.

Cottereau, A. and Marzok, M.-M. (2012) Une famille andalouse: Ethnocomptabilité d'une économie invisible. Paris: Bouchene.

Cozian, M. and Deboissy F. (2014) Précis de fiscalité des entreprises. Paris: LexisNexis.

Dewey, J. (1971) Le pragmatisme. Paris: Bordas.

Doganova, L. (2014) Décompter le futur. Sociétés contemporaines, 93(1): 67-87.

Erturk, I., Froud, J., Johal, S., Leaver, A. and Williams, K. (2007) Against agency: A positional critique. Economy and Society, 36(1): 51-77.

Erturk, I., Froud, J., Johal, S., Leaver, A. and Williams, K. (2010) Ownership matters: private equity and the political division of ownership. Organization, 17(5): 543-61.

Fama, E. (1970) Efficient capital markets: A review of theory and empirical work. The Journal of Finance, 25(2): 383-417.

Fligstein, N. (1990) The Transformation of Corporate Control. Cambridge, MA: Harvard University Press.

Fligstein, N. (2001) The Architecture of Markets. Princeton, NJ: Princeton University Press.

Fligstein, N. and Feeland, R. (1995) Theoretical and comparative perspectives on corporate organization. Annual Review of Sociology, 21(1): 21-43.

Foureault, F. (2014) Remodeler le capitalisme: Le jeu profond du Leveraged Buy-Out en France, 20012009. Thèse de doctorat.

Genette, G. (1969) Figures II. Paris: Editions du Seuil.

Glachant, J., Lorenzi, J.-H. and Trainar, P. (2008) Private equity et capitalisme français. Paris: La Documentation Française.

Godechot, O. (2009) Concurrence et coopération sur les marchés financiers: Les apports des études sociales de la finance. In: Steiner, P. and Vatin, F. (eds.) Traité de sociologie économique. Paris: PUF, 609-45.

Ho, K. (2009) Liquidated: An Ethnography of Wall Street. Durham, NC: Duke University Press.

Jensen, M. (1978) Some anomalous evidence regarding market efficiency. Journal of Financial Economics, 6(2-3): 95-101.

Krippner, G. (2005) The financialization of the American economy. Socio-Economic Review, 3(2): 173208.

Larminat, P. (2012) Spéculer pour autrui dans un monde incertain: Comment les investisseurs professionnels évaluent les gérants d'actifs financiers. Thèse de doctorat.

Larminat, P. (2016) Comment maîtriser le risque porté par les produits financiers? In: Chambost, I., Lenglet, M. and Tadjeddine, Y. (eds.) La fabrique de la finance: Pour une approche interdisciplinaire. Villeneuve d'Ascq: Presses universitaires du Septentrion, 28-32. 
Latour, B. (2012) Enquête sur les modes d'existence: Une anthropologie des modernes. Paris: La Découverte.

Lemoine, B. (2016) L'Ordre de la dette. Paris: La Découverte.

Lordon, F. (2000) La création de valeur comme rhétorique et comme pratique: Généalogie et sociologie de la valeur actionnariale. L'année de la régulation, 4: 117-65.

Lordon, F. (2008) Jusqu'à quand? Pour en finir avec les crises financières. Paris: Raisons d'Agir.

Mackenzie, D. and Millo, Y. (2003) Constructing a market, performing theory: The historical sociology of financial derivatives exchange. American Journal of Sociology, 109(1): 107-45.

Mandeville, B. (1998) [1714] La Fable des abeilles. Paris: Vrin.

Manigart, S., De Waele, K., Wright, M., Robbie, K., Desbrières, P., Sapienza, H. and Beekman, A. (2000) Venture capitalists, investment appraisal and accounting information: A comparative study of the USA, UK, France, Belgium and Holland. European Financial Management, 6(3): 389-403.

Morgenstern, O. and Von Neumann, J. (1944) Theory of Games and Economic Behaviour. Princeton, NJ: Princeton University Press.

Muniesa, F., Doganova, L., Ortiz, H., Pina-Stranger, A., Paterson, F., Bourgoin, A., Ehrenstein, V., Juven, P.-A., Pontille, D., Saraç-Lesavre, B. and Yon, G. (2017) Capitalization: A Cultural Guide. Paris: Presses des Mines.

Muniesa, F. and Teil, G. (2006) Donner un prix: Observations à partir d'un dispositif d'économie expérimentale. Terrains et travaux, 11(2): 222-44.

Orléan, A. (2011) L'Empire de la valeur. Paris: Seuil.

Ortiz, H. (2014) Valeur financière et vérité: Enquête d'anthropologie politique sur l'évaluation des entreprises cotées en bourse. Paris: Presses de Sciences Po.

O'Sullivan, M. (2007) Acting out institutional change: Understanding the recent transformation of the French financial system. Socio-Economic Review, 5(3): 389-436.

Savage, L. (1954) The Foundations of Statistics. New York: Dover Publications.

Steiner, P. and Vatin, P. (2009) Traité de sociologie économique. Paris: Presses universitaires de France.

Uzzi, B. and Lancaster, R. (2004) Embeddedness and price formation in the corporate law market. American Sociological Review, 69(3): 319-44.

White, H.C. (1981) Where do markets come from? American Journal of Sociology, 87(3): 517-47. 